PRACE GEOGRAFICZNE

zeszyt 149, 2017, 15-32

doi: 10.4467/20833113PG.17.008.6924

Instytut Geografii i Gospodarki Przestrzennej UJ

Wydawnictwo Uniwersytetu Jagiellońskiego

\title{
TRANSFORMACJA ENERGETYCZNA W POLSKIEJ GMINIE. SKUTKI POLITYKI LOKALNEJ OPARTEJ O ODNAWIALNE ŹRÓDŁA ENERGII NA PRZYKŁADZIE KISIELIC
}

\author{
Jan Frankowski
}

\section{Energiewende in a Polish commune. Consequences of local policy based on renewable energy sources, on the example of Kisielice}

Abstract: The increasing role of renewable energy sources implies significant socio-economic changes at the local level. In Poland, a great importance in that area is attached to wind turbines and biofuel-based combined heat and power stations. Localization of these investments often leads to social conflicts. The aim of this study is to assess the consequences of local policy in Kisielice, which in the years 1998 to 2015 gave priority to RES development. Considering this problem from the perspective of the energy justice framework and the law on wind energy investments, a case study has been investigated. The case study consists of: (1) literature review, including nine interviews with the local authorities (2) statistical and spatial analysis (3) fieldwork in five villages located in the direct neighbourhood of wind energy turbines. The results show that long-term local energy policy in Kisielice, implemented with an intensity comparable to the German Energiewende, has met the most of social acceptance conditions. Support for RES in the villages susceptible to anthropogenic influence displays similar patterns to trends at the national level. However, the inhabitants have a sense of injustice resulting from the fact that only a small group obtains benefits from the use of wind turbines. According to the author's opinion, a compromise between restrictive provisions of the law on wind energy investments and local community's interests can only be based on creating the atmosphere of trust and partnership, as well as implementing mechanisms of direct compensations for negative external effects created by renewable installations.

Keywords: renewable energy sources, energy justice, Kisielice, local development, wind energy 
Zarys treści: Wzrastająca rola odnawialnych źródeł energii implikuje istotne zmiany społeczno-gospodarcze na poziomie lokalnym. W Polsce główne znaczenie w tej kwestii mają elektrownie wiatrowe oraz oparte na biogazie lub biomasie elektrociepłownie, których lokalizacja często powoduje konflikty społeczne. Celem niniejszego artykułu jest ocena skutków lokalnej polityki energetycznej gminy Kisielice, która od 1998 do 2015 r. konsekwentnie uznawała odnawialne źródła energii jako swój priorytet rozwojowy. Osadzając zagadnienie w koncepcji sprawiedliwości energetycznej oraz przepisach tzw. ustawy odległościowej, przeprowadzono studium przypadku, na które złożyły się (1) przegląd literatury oraz materiałów prasowych, w tym dziewięciu wywiadów z władzami gminy; (2) analizy danych statystycznych i przestrzennych; (3) badania terenowe w pięciu miejscowościach położonych w bezpośredniej bliskości elektrowni wiatrowych. Wyniki wskazują, że długoletnia polityka energetyczna gminy Kisielice prowadzona w skali niemieckiej transformacji energetycznej spełniła większość warunków społecznej akceptacji. Poparcie dla odnawialnych źródeł energii w miejscowościach najbardziej narażonych na antropopresję elektroenergetyczną kształtuje się na poziomie ogólnopolskim, niemniej mieszkańcy odczuwają niesprawiedliwość wynikającą z wąskiej grupy bezpośrednich beneficjentów elektrowni wiatrowych. Zdaniem autora kluczem do kompromisu pomiędzy restrykcyjnymi zapisami tzw. ustawy odległościowej a zyskami budżetowymi samorządów z energetyki odnawialnej jest wykreowanie atmosfery zaufania i partnerstwa, a także wdrożenie bezpośrednich rekompensat za potencjalną uciążliwość lokalizacji dla wszystkich mieszkańców.

Stowa kluczowe: odnawialne źródła energii, sprawiedliwość energetyczna, Kisielice, rozwój lokalny, ustawa odległościowa

\section{Wzrastająca rola transformacji energetycznej w rozwoju lokalnym}

Odnawialne źródła energii pełnią funkcję głównego nośnika globalnej transformacji energetycznej. Proces transformacji energetycznej definiowany jest jako stopniowe przejście z tradycyjnej ścieżki dostaw energii do nowego systemu, opierające się na zmianach strukturalnych produkowanej energii pierwotnej, obserwowane zarówno w skali świata, państw, jak i na poziomie gospodarstwa domowego (Smil 2010). Obecnie świat nauki utożsamia transformację energetyczną nie tylko ze zmianą stosowanego paliwa, ale zmianą całych układów społeczno-gospodarczych i politycznych (Miller i in. 2013). Transformacja energetyczna wynika z kilku przyczyn. Po pierwsze, szacowane zasoby paliw kopalnych osiągają już wartości krytyczne i ich wydobycie staje się coraz mniej rentowne (Popkiewicz 2016). Po drugie, wzrost znaczenia odnawialnych źródeł energii powoduje dynamiczny rozwój technologii. Po trzecie, istotnie wzrasta świadomość potencjału naturalnych źródeł energii w społeczeństwie. Do wymienionych kwestii należy dodać również wolę oraz determinację części liderów politycznych (Manwell i in. 2009). Determinacja dla wdrażania odnawialnych źródeł energii w sektorze energetycznym cechowała przede 
wszystkim władze wysoko rozwiniętych krajów, takich jak Dania czy Niemcy, ale w odnawialne źródła energii coraz silniej inwestują także dynamicznie rozwijające się Chiny oraz państwa afrykańskie.

Energia jest kluczowym czynnikiem napędzającym gospodarkę. Szczególnie produkcja i konsumpcja energii elektrycznej są konieczne do trwałego rozwoju gospodarczego. Coraz większe potrzeby w zakresie elektryczności zgłaszają gospodarstwa domowe. Wskazuje na to także teoria drabiny energetycznej (WHO 2008). Zgodnie $\mathrm{z}$ tą teorią gospodarstwa domowe na najniższym poziomie rozwoju używają do codziennych czynności wymagających użycia energii, takich jak gotowanie czy ogrzewanie najpierw biomasy, następnie paliw stałych i ciekłych (torfu, węgla, nafty), na samym końcu zaś gazu naturalnego oraz elektryczności (van Ruijven i in. 2008). Wraz ze wzrostem dochodów rośnie tym samym zapotrzebowanie na energię elektryczną, a także komfortowe i ekologiczne źródło ciepła. Coraz częściej głównym nośnikiem energii staje się elektryczność, ponieważ na rzadziej zaludnionych obszarach o utrudnionym dostępie do sieci infrastrukturalnych to odnawialne źródła zaczynają zapewniać ciepło mieszkańcom. Co więcej, rzadziej zaludnione i słabiej rozwinięte obszary wiejskie w przeciwieństwie do miast dysponują areałem, na którym można lokować instalacje produkujące energię.

Dotychczasowy model zarządzania energetyką, oparty na państwowym, scentralizowanym zarządzaniu siecią elektroenergetyczną oraz dużych elektrowniach, których podstawą są paliwa kopalne, ustępuje bardziej elastycznym, rozproszonym źródłom, wykorzystującym do produkcji zasoby słońca, ziemi, wiatru, wody i biosfery. Państwo tym samym powoli traci swój monopol na energię, a jej rozproszona produkcja w pierwszej kolejności na potrzeby lokalne zwiększa efektywność i elastyczność całego systemu (Alanne, Saari 2006). Dzięki odnawialnym źródłom energii samorządy mogą kreować rozwój lokalny, rozumiany w pracy jako proces zmian w układzie lokalnym, w wyniku których zwiększa się suma szans indywidualnego rozwoju poszczególnych mieszkańców (Kłosowski, Warda 2001).

Możliwości rozwojowe dzięki odnawialnym źródłom energii wynikają przede wszystkim z regularnych transferów podatkowych do budżetów gmin od przedsiębiorców oraz właścicieli ziemskich, a także osób pracujących przy instalacjach OZE. W przypadku elektrociepłowni opartej na źródłach odnawialnych lokalna społeczność może także uzyskać dodatkowy punkt zbytu dla produktów rolnych. Najistotniejszym źródłem dochodu jest podatek od nieruchomości płacony od dzierżawy pola pod turbinę wiatrakową, linię przesyłową lub elektrociepłownię, dodatkową zaś korzyść dla samorządów stanowią darowizny oraz inwestycje o charakterze publicznym, finansowane przez inwestorów. Zwiększanie bazy dochodowej jest szczególnie istotne dla gmin gwałtownie tracących mieszkańców w mniej zamożnych regionach. Wkład otrzymany z produkcji energii pozwala gminom częściowo uniezależnić się od wsparcia państwa, choć zdaniem przeciwników 
odnawialnych źródeł jest on okupiony zbyt wysokim kosztem środowiskowym, ekonomicznym i społecznym. Odnawialne źródła energii, które w skali makro redukują zależność od paliw kopalnych, nie zawsze powodują pozytywne rezultaty na poziomie mikro. Stosunek do poszczególnych rodzajów odnawialnych źródeł energii różni nawet polskich ekologów i specjalistów z zakresu ochrony środowiska (Popkiewicz 2016).

Najwięcej kontrowersji budzą elektrownie wiatrowe, które wpływają negatywnie na środowisko, uśmiercając ptaki, nietoperze i mechanizując krajobraz (Niecikowski, Kistowski 2008). Wśród niekorzystnych oddziaływań elektrowni wiatrowych wskazywane są także przekształcenia wierzchnich warstw gleby i utrata powierzchni biologicznie czynnej na etapie budowy, a także cień ograniczający dostęp promieni słonecznych oraz osłabianie siły wiatru w bezpośredniej bliskości turbiny na etapie eksploatacji (Wiklent, Kistowski 2013). Często wskazywaną uciążliwością elektrowni wiatrowych jest także hałas wynikający z błędów w lokalizacji lub posadowienia turbin starszego typu (Wiśniewski i in. 2012). Odgłosy wiatraków są bardziej uciążliwe niż inne źródła hałasu o tej samej częstotliwości, ale wpływ na zdrowie lub jakość snu pozostaje niejednoznaczny (Pawlas i in. 2012). Inne źródła dowodzą, że infradźwięki i dźwięki o niższej częstotliwości nie wpływają istotnie na większe ryzyko utraty zdrowia, dostrzegając jednocześnie związek bliskości farm wiatrowych z większym rozdrażnieniem (McCunney i in. 2014). W przypadku biogazowni krytycy wskazują przede wszystkim potencjalne zagrożenie wybuchem oraz emitowanie fetoru. Choć obecne instalacje nie powodują uciążliwych zapachów, pierwsze biogazownie były wadliwe, co wywołało dystans do tej technologii w społeczeństwie (Pasławski 2013).

Obok argumentów ekologicznych przeciwnicy odnawialnych źródeł energii często przywołują argumenty ekonomiczne, podkreślając słabość omawianych technologii w porównaniu z paliwami kopalnymi. Pomijając długi okres zwrotu z instalacji, turbiny wiatrowe, a także ogniwa fotowoltaiczne, są niestabilnymi źródłami energii. Niestabilność powoduje zakłócenia w sieci elektroenergetycznej, nie pozwala także efektywnie wykorzystać pełni zainstalowanego potencjału.

Obecne rozwiązania prawne w Polsce umożliwiają czerpanie bezpośrednich korzyści wyłącznie właścicielom ziemi, pomimo że turbiny wiatrowe istotnie ingerują w krajobraz będący przecież dobrem wspólnym. Nierówność w dystrybucji ponoszonych kosztów i zysków z produkowanej energii wiąże się z pojęciem sprawiedliwości energetycznej (energy justice). Sprawiedliwość energetyczna to sytuacja, w której system energetyczny równomiernie rozdziela koszty i zyski usług, każda zainteresowana strona posiada natomiast swe przedstawicielstwo podejmujące decyzje bezstronnie i obiektywnie (Sovacool, Dworkin 2015). Przykładami braku sprawiedliwości energetycznej może być nierówny dostęp do usług transportoł wych i energetycznych oraz różne obciążenie kosztem polityk niskoemisyjnych 
(Simcock, Mullen 2016). Ten ostatni wątek najsilniej wpisuje się w kontrowersje z wykorzystaniem odnawialnych źródeł energii.

W Polsce akceptacja społeczna dla energetyki odnawialnej jest wysoka i sięga ok. 80\% (Łucki, Misiak 2010 - 82\%; TNS 2013 - 78\%). Na podstawie studium przypadku czterech powiatów wskazano, że nie ma dowodów na pogłębianie się negatywnego stosunku do energetyki wiatrowej wraz z wiekiem (Marcinkiewicz, Poskrobko 2015). Badania przeprowadzone w pięciu województwach dowodzą, że obecność farm wiatrowych w pobliżu terenów zabudowanych nie wpływa istotnie negatywnie na jakość życia, wyłączając tereny, w pobliżu których planowane są tego rodzaju inwestycje. Może to świadczyć o silnym stresie oraz obawach przed inwestycjami w OZE (Mroczek i in. 2015) i pozwala przypuszczać, że ogólne deklaracje popierające źródła odnawialne niekoniecznie pokrywają się $\mathrm{z}$ indywidualnym przyzwoleniem na budowę tego rodzaju instalacji w miejscu swego zamieszkania.

W latach 2006-2014 aż 20\% wszystkich konfliktów lokalnych w Polsce stanowiły konflikty związane $\mathrm{z}$ energetyką wiatrową, występujące aż w 102 gminach (Bednarek-Szczepańska 2016). Konflikty te generują napięcia, wiążą się bowiem z wysokimi korzyściami dla niewielkich grup osób, konsekwencje zaś, chociażby w postaci trwałych zmian krajobrazu, muszą ponosić wszyscy mieszkańcy gminy. Podobne kontrowersje budzą biogazownie, gdzie istotniejszym problemem jest jednak niewielka wiedza mieszkańców na temat działania tej technologii.

Inwestycje w odnawialne źródła energii mogą jednak zyskać aprobatę lokalnej społeczności. Warunkiem społecznej akceptacji są następujące czynniki:

- lokalne zakorzenienie (np. odwołanie do tradycji gminy);

- ciągłość z istniejącymi strukturami fizycznymi, społecznymi i kognitywnymi (np. lokalizacja farmy wiatrowej lub fotowoltaicznej na terenie byłego Państwowego Gospodarstwa Rolnego - ponowne nadanie funkcji produkcyjnej); - korzyści lokalne (np. transparentne korzystanie z pieniędzy pozyskanych z OZE); - dobre procedury komunikacyjne i partycypacyjne (uczciwa dyskusja o potencjal-

nych lokalizacjach, kosztach oraz konsekwencjach) (Łucki, Misiak 2010).

Kreowanie odpowiednich warunków do rozwoju energii odnawialnej wymaga nie tylko proaktywnej i asertywnej postawy władz gminy, lecz również motywacji i mobilizacji państwa. Tymczasem w 2016 roku polski sejm uchwalił tzw. ustawę odległościową, istotnie hamującą dynamiczny rozwój tej gałęzi polskiej energetyki.

W Polsce dominujące ugrupowania polityczne stawiają przede wszystkim na węgiel, starając się utrzymywać ceny prądu na możliwie niskim i stabilnym poziomie. Wzrost cen prądu wywołałby spadek poparcia politycznego, a odstąpienie od węgla pogorszenie nastrojów społecznych na Górnym Śląsku. Uzyskanie samodzielnej władzy przez Prawo i Sprawiedliwość w 2015 r. zmieniło także politykę względem niektórych rodzajów odnawialnych źródeł energii. Wśród technologii, które 
w największym stopniu straciły poparcie państwa, znalazła się energetyka wiatrowa (Strategia na Rzecz... 2016).

Konieczność uregulowania przepisów w zakresie lokalizacji farm wiatrowych postulował raport Najwyższej Izby Kontroli, negatywnie oceniając rozwój energetyki wiatrowej w Polsce. Zdaniem NIK gminy w kwestii lokalizacji turbin wiatrowych działały nietransparentnie, cały zaś mechanizm był korupcjogenny - ponieważ aż 30\% wszystkich wiatraków posadowiono na gruntach osób związanych z lokalną władzą (NIK 2014). Rząd wyszedł także naprzeciw inicjatywie społecznej stop-wiatrakom.eu, która od dłuższego czasu lobbowała za regulacją odległości turbin wiatrowych od zabudowy. Nowa ustawa weszła w życie 1 lipca 2016 r., bez wcześniejszych konsultacji społecznych oraz oceny skutków regulacji. Prawo to wprowadziło definicję elektrowni wiatrowej oraz uzależniło lokalizację turbin od miejscowego planu zagospodarowania przestrzennego. Najwięcej kontrowersji wzbudziło jednak określenie minimalnej odległości dla nowo powstających obiektów - rzędu dziesięciokrotności długości wiatraka ze śmigłem od zabudowań mieszkalnych, mieszanych oraz obszarów cennych przyrodniczo (Ustawa... 2016).

Pół roku po ogłoszeniu ustawy trudno mówić o konsekwencjach przeprowadzonych zmian. Przeciwnicy i zwolennicy rzadko posługują się rzetelnym i jednoznacznym materiałem dowodowym. Zdecydowana większość społeczeństwa i sceny politycznej zdaje sobie sprawę z potrzeby poszerzania udziału odnawialnych źródeł energii w miksie energetycznym - kwestią sporną pozostaje tempo wprowadzanych zmian. Stosunkowo rzadko podejmowane są natomiast próby oceny wartościującej dotychczasowe polityki samorządów inwestujących w odnawialne źródła energii. Niniejszy artykuł ma na celu tę lukę zapełnić.

\section{Założenia studium przypadku giminy Kisielice}

Gmina Kisielice stanowi popularny przykład dobrych praktyk lub studiów przypadku lokalnej polityki energetycznej w raportach oraz portalach branżowych (Wiśniewski i in. 2012; Kohoroda 2014; Regulski i in. 2016). Istniejące opracowania koncentrują się jednak na syntetycznym opisie przeprowadzonych inwestycji w tym najciekawszym poligonie lokalnej transformacji energetycznej w Polsce. Artykuł uzupełnia te informacje o ocenę skutków lokalnej polityki energetycznej wraz z rozpoznaniem jej odbioru społecznego w obszarach najbardziej narażonych na antropopresję ekoenergetyczną.

Zakres przedmiotowy pracy objął politykę lokalną, rozumianą jako deklaracje w dokumentach strategicznych oraz konkretne inwestycje związane z energią, ze szczególnym uwzględnieniem elektrowni wiatrowych, a także elektrociepłowni opartej na biogazie i biomasie. W badaniu analizowano przedział czasowy 1998-2016. 
O ile analiza polityki lokalnej dotyczyła całej gminy Kisielice, o tyle zakres podmiotowy objął 61 gospodarstw domowych w pięciu miejscowościach położonych najbliżej farm wiatrowych wybudowanych w latach 2004-2014 (Łodygowo, Klimy, Pławty Wielkie, Łęgowo, Biskupiczki).

Do realizacji artykułu wykorzystano następujące metody: (1) przegląd literatury oraz materiałów prasowych, w tym dziewięć wywiadów przeprowadzonych z władzami gminy w latach 2011-2016; (2) analizę danych statystycznych i przestrzenh nych; (3) badania terenowe gospodarstw domowych we wskazanych wcześniej pięciu miejscowościach. Na początku pracy omówiono politykę energetyczną oraz zyski ekonomiczne gminy Kisielice, używając przede wszystkim metod (1) oraz (2), następnie zaś poddano badaniu opinię społeczną. Szczegółowy opis metodyki badań terenowych znalazł się w rozdziale 5. Cytowane informacje z wywiadów udzielonych przez lokalnych liderów zostały oznaczone symbolami od W1 do W9, a następnie umieszczone w spisie literatury.

Artykuł przyjmuje perspektywę geograficzną, która wydaje się najlepsza do podjęcia studiów związanych z odnawialnymi źródłami energii (Solomon i in. 2004). W badaniach anglosaskich od lat geografia energii stanowi istotny nurt, zgłębiając miejski i przestrzenny wymiar relacji energetyki z globalnym ociepleniem, sprawiedliwością społeczną, bezpieczeństwem i środowiskiem miejskim (Pasqualetti 2011; Calvert 2016). Energetyka rzadko stanowi jednak przedmiot zainteresowania polskich geografów. W polskich ośrodkach geograficznych wymiar terytorialny energetyki wydaje się niedoceniany (Komornicki 2016) i to przy sporym zapotrzebowaniu samorządów lokalnych, w których problemy na przecięciu energetyki, środowiska i przestrzeni są coraz bardziej dostrzegalne.

\section{Polityka energetyczna gminy Kisielice w latach 1998-2015}

Gmina Kisielice znajduje się w powiecie iławskim, w zachodniej części województwa warmińsko-mazurskiego. Większość terenu gminy zajmują lasy oraz użytki rolne (71,2\%), co przekłada się na niską gęstość zaludnienia. W 2015 r. gminę Kisielice zamieszkiwało 6055 mieszkańców, a udział bezrobotnych zarejestrowanych w liczbie ludności w wieku produkcyjnym kształtował się na poziomie 4,3\%. Układ osadniczy gminy stanowi centralnie położone miasto Kisielice oraz 21 miejscowości zgrupowanych w 14 sołectwach. Rolniczy charakter gminy, podobnie jak położenie w strefie korzystnych zasobów wiatru (Lorenc 1996), zapewniają wysoki potencjał rozwoju odnawialnych źródeł energii.

Zainteresowanie władz gminy odnawialnymi źródłami energii było umotywowane chęcią pozyskania dodatkowych dochodów do budżetu (W4). Sprzyjały temu także tradycje wykorzystania wiatraków w gminie za czasów pruskich oraz 
równoległy rozwój turbin wiatrowych w Niemczech i Danii (W1). Kierując się tymi czynnikami, w 1998 r. władze lokalne dopuściły w planie zagospodarowania posadowienie turbin wiatrowych. W kolejnym strategicznym dokumencie gminy Strategii Gminy i Miasta Kisielice na lata 2000-2010 - założono zwiększenie udziału paliw ekologicznych i odnawialnych (Strategia... 2007). W 2002 r. władze zleciły Ocene zasobów wiatru i studium wykonalności dla sitowni wiatrowej w gminie Kisielice. Ekspertyza ta miała stworzyć podstawę budowy elektrowni wiatrowej ze środków własnych, co jednak zakończyło się niepowodzeniem. Dopiero po wejściu Polski do Unii Europejskiej w 2004 r. inwestycje w odnawialne źródła energii w gminie Kisielice nabrały realnego kształtu.

W 2004 r. uzgodniono pierwszy projekt farmy wiatrowej w Łodygowie, któn rej budowa zaczęła się dwa lata później. Równolegle do farmy wiatrowej gmina rozpoczęła budowę elektrociepłowni na słomę, która poprzez sieć ciepłowniczą zasila budynki samorządowe i mieszkalne w Kisielicach. Rozbudowę sieci ciepłowniczej kontynuowano dzięki funduszom europejskim w latach 2007-2009 oraz 2010-2013. Aktywna polityka energetyczna gminy zachęcała kolejnych inwestorów. W 2008 r. rozpoczęto budowę kolejnej farmy wiatrowej Łęgowo, położonej także na terenie sołectw Klimy oraz Pławty Wielkie. Inwestycja została uzupełniona dwoma głównymi punktami zasilania oraz linią wysokiego napięcia przesyłającą energię do Krajowego Systemu Elektroenergetycznego. Liczba wiatraków na terenach trzech wspominanych miejscowości sukcesywnie rosła, były też one lokowane mniej regularnie niż w przypadku farmy Łodygowo.

W 2012 r. władze Kisielic podjęły starania, aby mieszkańcy gminy bezpośrednio odczuli korzyści inwestycji energetycznych. Warmińsko-Mazurska Agencja Energetyczna przeszkoliła 100 rolników z pozyskiwania oraz zbytu biomasy, dzięki czemu część dostarcza uprawy na rzecz kisielickiej ciepłowni. W 2013 r. rozpoczęto budowę biogazowni opartej na kiszonce kukurydzianej w bezpośredniej bliskości ciepłowni, dzięki czemu gmina oszczędza środki, wykorzystując droższą słomę jako dodatek podczas najniższych temperatur, a latem zupełnie rezygnując z tego paliwa (Krzemiński 2014). Ostatni okres rozwoju odnawialnej energii w gminie Kisielice to przede wszystkim budowa ośmiu największych turbin w miejscowościach Jędrychowo i Trupel.

Analizując rozwój OZE w ciągu 10 lat, można zauważyć, że sukcesywnie zmniejszała się liczba, wzrastała natomiast wysokość oraz moc wiatraków. Obok przedstawionych wyżej największych inwestycji należy także wspomnieć o mniejszych inicjatywach, takich jak wymiana pieca węglowego na biomasę w szkole podstawowej w Łęgowie lub instalacja paneli fotowoltaicznych na dachu ciepłowni miejskiej. W 2015 r. władze Kisielic uchwaliły także Plan Gospodarki Niskoemisyjnej jako kolejny dokument wskazujący na istotną rangę polityki energetycznej w gminie (Plan Gospodarki Niskoemisyjnej... 2015). 


\section{Kreowanie rozwoju lokalnego dzięki odnawialnym źródłom energii}

Dochody z odnawialnych źródeł energii mogą przynosić wymierne korzyści samorządom lokalnym. Korzyści te są widoczne przede wszystkim w postaci podatku od nieruchomości, który obok udziału samorządu w PIT stanowi główny wkład do budżetu gmin. Właściciel ziemi, na którego terenie inwestor zlokalizował instalacje OZE, rokrocznie uiszcza podatek od nieruchomości. W przypadku turbin wiatrowych podatek od nieruchomości wynosi $2 \%$ od wartości instalacji, licząc fundamenty oraz maszt. Spoglądając na wysokość podatku od nieruchomości w Kisielicach od 2004 r., widoczny jest wyraźny przyrost transferów finansowych wraz z oddawaniem kolejnych wiatraków. Istotna jest także zmiana strukturalna - już od 2006 r. wpływy z podatku od nieruchomości były wyższe niż z podatku rolnego. Ostatecznie dochody z inwestycji energetycznych, wynoszące prawie $3 \mathrm{mln}$ zł, stanowiły kilkanaście procent dochodów w budżecie gminy na 2016 r. (W9). Ogólnodostępne dane statystyczne uniemożliwiają precyzyjne wskazanie kwoty płaconej przez dzierżawców ziemi, niemniej należy się spodziewać, że dochody te stanowią większość wpływów z podatku od nieruchomości w gminie. Do tych kwot należy także dodać podatki osób zatrudnionych na czas budowy instalacji oraz niewielkie opłaty administracyjne. Uzyskane wpływy zagwarantowały stabilizację budżetu, a także zapewniły wkład własny do licznych inwestycji infrastrukturalnych ze środków Unii Europejskiej.

Wśród zrealizowanych inwestycji poprzedni burmistrz wskazywał oczyszczalnię ścieków oraz kanalizację, drogi, chodniki, promenadę spacerową, infrastrukturę społeczną (orlik, hale sportowe, boiska szkolne, świetlice wiejskie, amfiteatr) i kryzysową (remiza, sprzęt strażacki, gminne centrum reagowania), a także uzbrojenie terenów pod dalsze inwestycje (W9). Gmina Kisielice znalazła się tym samym w drugim kwintylu najbardziej wspartych ze środków UE jednostek w Polsce w latach 2007-2015 (Regulski i in. 2016).

Czterej główni inwestorzy związani z energetyką wiatrową także zaangażowali się w projekty infrastrukturalne. Wyremontowano drogę wojewódzką 522 z Sobiewoli do granicy regionu, drogę powiatową Bałoszyce-Pławty Wielkie, a także podjęto deklarację odnowy dwóch dróg wiejskich w Jędrychowie oraz szosy z Trupla do Szwarcenowa (W2). Inwestorzy regularnie sponsorują także dożynki oraz inne imprezy wiejskie.

Prócz transferów do budżetu oraz inwestycji w gminie poprawiła się jakość powietrza oraz zmniejszono emisję $\mathrm{CO}_{2}$ o 182 tys. t, głównie dzięki wymianie pieców w miejskiej ciepłowni oraz podłączeniu $85 \%$ budynków w Kisielicach do sieci ciepłowniczej (W3). Dzięki konsekwentnej polityce lokalnej wzrosła świadomość społeczna korzystania z OZE, wykreowano również pozytywny wizerunek gminy, która jest rozpoznawalnym przykładem proaktywnej polityki energetycznej w Polsce i Europie. 
Zdaniem lokalnej władzy społeczność Kisielic cechuje przychylny stosunek do odnawialnych źródeł energii (W1, W5, W6). Jeszcze przed wejściem do Unii Europejskiej gmina rozpoczęła kampanię edukacyjną wskazującą korzyści wynikające z OZE, która rozbudziła oczekiwania społeczne. Znaczna część mieszkańców zabiegała o to, aby wiatraki stanęły na ich gruncie, a szczególnie starsi mieszkańcy miasta wywierali presję na rozbudowę sieci ciepłowniczej ze względu na dużo większy komfort ogrzewania miejskiego w stosunku do pieców na paliwa stałe (W4). W przeciwieństwie do innych gmin w Polsce w Kisielicach nie zanotowano istotnych konfliktów związanych z inwestycjami energetycznymi. Perspektywa odczuwalnych korzyści, a także strategiczna konsekwencja władz, przekonywały i utrzymywały poparcie mieszkańców dla inwestycji w odnawialne źródła energii. Zarzewiem niewielkiego konfliktu stała się jedynie informacja o budowie biogazowni, której sprzeciwiało się kilkudziesięciu mieszkańców. Władze gminy zorganizowały wówczas wyjazd do niemieckiej gminy, w trakcie którego nieprzekonane osoby mogły w praktyce poznać funkcjonowanie biogazowni i przekonać się o jej znaczeniu dla lokalnej gospodarki (W4).

Pomimo stabilnego budżetu, licznych inwestycji oraz pozytywnego stosunku mieszkańców do odnawialnych źródeł energii wieloletni burmistrz Tadeusz Koprowiak - główna osoba odpowiedzialna za kreowanie rozwoju w Kisielicach - przegrał jednak wybory samorządowe w 2014 r. Przyjmując odnawialne źródła energii jako jeden z głównych pomysłów na rozwój gminy poprzedniego burmistrza, warto zadać pytanie, czy lokalna polityka energetyczna jako wizytówka gminy utraciła tym samym swój mandat społeczny.

\section{Stosunek mieszkańców do odnawialnych źródeł energii ze szczególnym uwzględnieniem energetyki wiatrowej}

W badaniu terenowym zdecydowano się poznać bliżej opinię na temat odnawialnych źródeł energii oraz polityki lokalnej mieszkańców miejscowości najbardziej narażonych na antropopresję ekoenergetyczną. Wyznaczono w gminie pięć miejscowości położonych najbliżej inwestycji energetycznych zrealizowanych w latach 2004-2014. Zakres badań objął poligony (ryc. 1), wewnątrz których znalazły się gospodarstwa domowe w promieniu 1-1,5 km od wiatraków. Ankieta przeprowadzona w ramach badań terenowych składała się z pięciu bloków pytań zamkniętych, które dotyczyły: (1) wpływu inwestycji na życie codzienne oraz składowe rozwoju lokalnego (atrakcyjność turystyczną, krajobrazową i osiedleńczą); (2) potencjalnych zysków z elektrowni wiatrowych; (3) obecności inwestorów w gminie; (4) preferowanej odległości; a także (5) stosunku do odnawialnych źródeł energii. Na końcu ankiety znalazła się metryczka, w której zapytano o płeć, wiek, wykształcenie oraz sytuację zawodową. Badania terenowe przeprowadzono w listopadzie 2016 r. w miejscu zamieszkania 


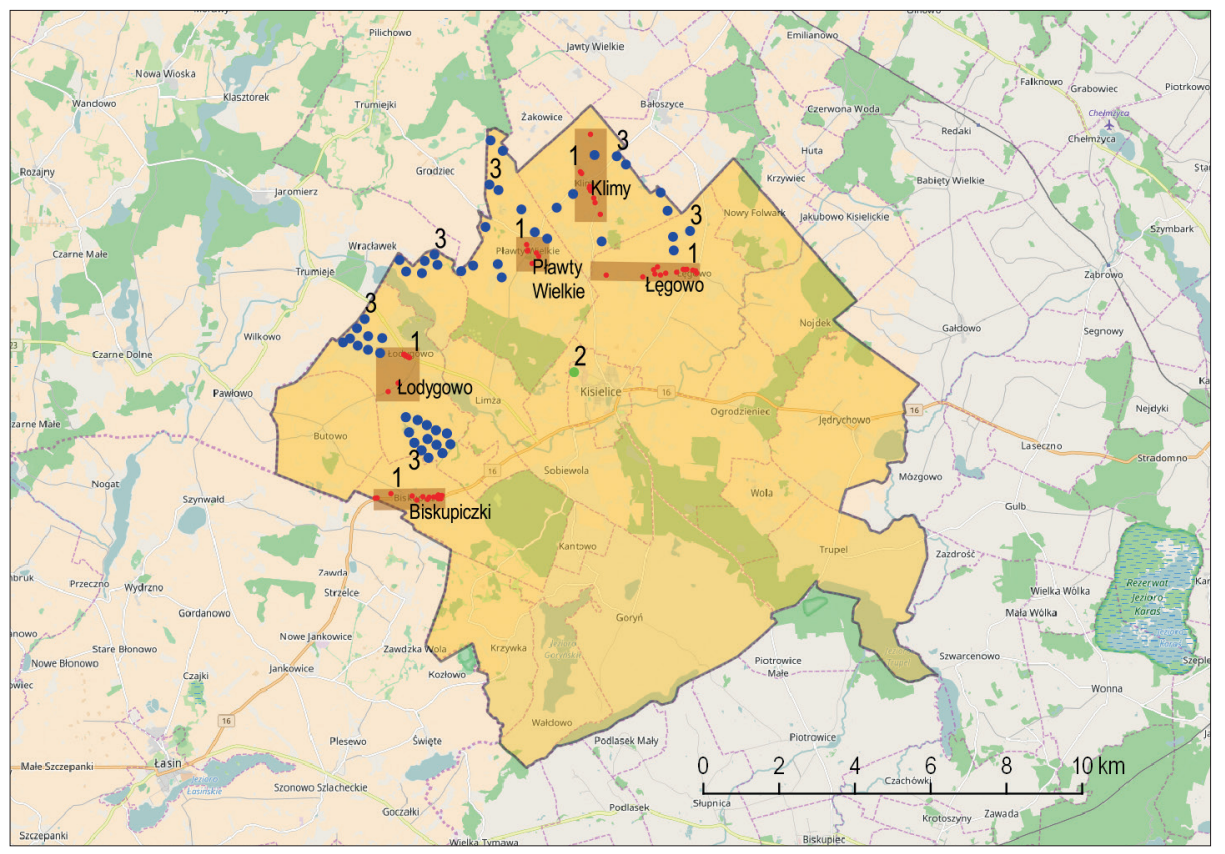

Ryc. 1. Tereny badania w gminie Kisielice

Fig. 1. Fieldwork area in Kisielice

Objaśnienia: 1 - poligony badawcze z zaznaczonymi adresami; 2 - biogazownia; 3 - turbiny wiatrowe wybudowane do $2014 \mathrm{r}$.

Explanations: 1 - research polygons with marked addresses; 2 - biogas plant; 3 - wind turbines built until 2014.

Źródto: opracowanie własne na podstawie OpenStreetMap (http://www.openstreetmap.org/, 15.12.2016). Source: own elaboration on the basis of OpenStreetMap (http://www.openstreetmap.org/, 15.12.2016). 
respondentów. Przyjęto zasadę, że każdy respondent należał do innego gospodarstwa domowego. Ostatecznie próba przedstawia się następująco:

- Biskupiczki (1100-1500 m od farmy wiatrowej) - 16 gospodarstw;

- Łodygowo (600-900 m od farmy wiatrowej) - 14 gospodarstw;

- Pławty Wielkie/Klimy (400-800 m od najbliższych turbin wiatrowych) - 17 gospodarstw;

- Łęgowo (500-1000 m od najbliższych turbin wiatrowych, od miejscowości Pławty do skrzyżowania z drogą wojewódzką) - 14 gospodarstw.

Badanie objęło łącznie 61 respondentów z różnych gospodarstw domowych. Ponad $3 / 4(78 \%)$ respondentów posiadało wykształcenie średnie, $16 \%$ podstawowe i jedynie $6 \%$ wyższe - co pokrywa się ze strukturą wykształcenia w gminie. $60 \%$ osób stanowiły osoby pracujące, $30 \%$ odpowiedzi udzielili emeryci i renciści, wśród pozostałych $10 \%$ znalazły się osoby bezrobotne, opiekunowie niepełnosprawnych dzieci oraz pełnoletni uczniowie lub studenci. Po przeprowadzeniu badań terenowych adresy gospodarstw domowych zostały naniesione na mapę i połączone z bazą odpowiedzi ankietowych w celu dokonania analiz przestrzennych.

Zdaniem respondentów turbiny wiatrowe mają niewielki wpływ na różne sfery atrakcyjności gminy. Ponad połowa respondentów nie dostrzega żadnego wpływu wiatraków na społeczność gminy, przyrodę czy ruch turystyczny. Pozytywne odpowiedzi dominują w przypadku atrakcyjności krajobrazu, co pozwala wysnuć przypuszczenie, że część mieszkańców zdołała nawet polubić wiatraki, wyraźnie dominujące w rolniczym krajobrazie gminy. Minimalnie więcej osób (27\% w stosunku do 25\%) negatywnie oceniło wpływ elektrowni wiatrowych na przyrodę. Niektórzy respondenci twierdzili, że liczba ptaków na terenie miejscowości jest mniejsza niż przed budową elektrowni wiatrowych, część natomiast wskazywała, że ptaki zmieniły swe miejsca bytowania tylko na jakiś czas i obecnie sytuacja wróciła już do normy. Mieszkańcy Łodygowa oraz Biskupiczek pozytywniej ocenili wpływ farm wiatrowych na turystykę i krajobraz - prawdopodobnie dlatego, że najbliżej położona farma wiatrowa w Łodygowie istnieje już prawie 10 lat, a wiatraki są tam usytuowane bardziej regularnie niż w Klimach, Pławtach Wielkich i Łęgowie. Być może gorzej wpływ wiatraków na krajobraz oceniliby mieszkańcy miasta Kisielice, gdzie turbiny istotnie zaburzają panoramę miasta z tradycyjną dominantą kościoła pw. Matki Bożej Królowej Świata (Gadomska, Antolak 2014).

Hałas emitowany przez turbiny jako niedogodność wskazała ponad 1/3 ankietowanych. W większości byli to mieszkańcy Klim, Pławt Wielkich oraz Łęgowa, gdzie zabudowa położona jest najbliżej turbin. $26 \%$ respondentów ze wszystkich miejscowości wskazało także czasowe zakłócenia sygnału telewizyjnego, choć trudno jednoznacznie powiązać je z obecnością turbin wiatrowych. W Klimach jeden z respondentów wśród niedogodności dodał ponadto miotanie kawałków lodu ze śmigieł wiatraków na jezdnię, co stwarzało zimą zagrożenie dla ruchu samochodowego. 
W badanych miejscowościach gminy Kisielice poparcie dla odnawialnych źródeł energii jest zbliżone do krajowego. Ponad 80\% respondentów zgodziło się ze stwierdzeniem, że państwo powinno zwiększać udział OZE w produkcji energii oraz wspierać energetykę prosumencką. Podobna część uczestników badania była zdania, że gmina powinna kontynuować inwestycje w odnawialne źródła energii. Należy jednak zauważyć, że mniejszy udział osób (60\%) uważa, że dzięki wiatrakom gmina rozwija się lepiej, 1/4 zaś nie zgadza się na posadowienie nowych turbin w gminie. Trudno dostrzec jednoznaczne prawidłowości, spoglądając na grupy wiekowe, płeć oraz status zawodowy respondentów. Na podstawie wyników można jedynie zaryzykować stwierdzenie, że poparcie dla OZE jest nieco wyższe wśród rolników i niższe u osób z wykształceniem podstawowym.

Najbardziej pozytywny stosunek do OZE cechował mieszkańców miejscowości najbardziej oddalonych od turbin wiatrowych. O ile w Klimach, Pławtach oraz Łęgowie nadal większość osób była przychylna OZE, o tyle wiatraki cieszyły się mniejszą sympatią niż inne technologie (np. ogniwa fotowoltaiczne, pompy ciepła). Pomimo słabszej sympatii znaczna część mieszkańców wszystkich pięciu miejscowości (48\%) chętnie udostępniłaby teren działki pod wiatrak, mając świadomość dochodów sięgających średnio 35 tys. zł rocznie (W7).

O ile jednak wyraźnie lepszy status materialny gospodarstw dzierżawiących ziemię pod wiatrak jest widoczny gołym okiem, o tyle respondenci dużo słabiej kojarzą działalność samych inwestorów. W Klimach, Pławtach Wielkich i Łęgowie, gdzie wiatraki są najmłodsze i położone najbliżej zabudowań, połowa respondentów dostrzega ich obecność podczas bieżących działań naprawczych oraz imprez wiejskich. W trakcie badań natrafiono tylko na jedną osobę pracującą dorywczo przy stawianiu wiatraków. Żaden z respondentów nie podał natomiast nazw firm, które posiadają wiatraki, ani nie wskazał kogoś z rodziny, kto pracowałby na stałe przy serwisowaniu turbin. Prawdopodobnie inwestorzy wykorzystują do tego celu firmę zewnętrzną, obsługującą kilka farm wiatrowych w różnych powiatach - stąd też wpływ wiatraków na zatrudnienie w gminie jest śladowy. Mieszkańcy badanych miejscowości często wspominali proces przewożenia turbin, ponieważ wymagał demontażu znaków drogowych oraz płotów części gospodarstw. Informacje o konieczności przewozu często były traktowane jako konsultowanie lokalizacji farm wiatrowych, stąd też wynik pozytywnych odpowiedzi w ankiecie należy uznać za nieco przeszacowany (48\%). Część mieszkańców deklarowała jednak, że pamięta zebrania oraz konsultacje organizowane przez władze lokalne - zwłaszcza mieszkańcy Łęgowa, Klim oraz Pławt Wielkich.

O ile większość respondentów uważa, że warto inwestować w OZE i gmina Kisielice dzięki nim rozwija się lepiej, o tyle jedynie $37 \%$ było zdania, że korzyści z wiatraków są sprawiedliwie rozdzielane przez gminę (ryc. 2). Tylko sześć osób (10\% próby) zadeklarowało czerpanie bezpośrednie korzyści (albo posiadanie w rodzinie kogoś, kto czerpie korzyści) z posadowienia turbin wiatrowych - zazwyczaj 
dzięki wiatrakom gmina rozwija się lepiej niż inne dostrzegam obecność inwestorów w gminie byłem osobiście informowany o planach budowy korzyści są sprawiedliwie dzielone przez gminę miałem wpływ na lokalizację wiatraków w okolicy mam poczucie korzystania z obecności wiatraków korzystam finansowo z obecności wiatraków

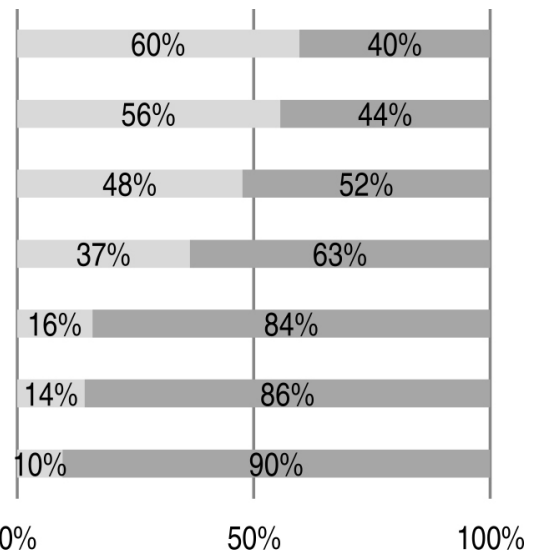
TAK $\square \mathrm{NIE}$

Ryc. 2. Odczucia przedstawicieli gospodarstw domowych dotyczące elektrowni wiatrowych Fig. 2. Opinions of the household representatives about the wind turbines Źródto: opracowanie własne na podstawie przeprowadzonego badania ankietowego ( $\mathrm{n}=61)$.

Source: own elaboration on the basis of the conducted survey research $(n=61)$

w formie dzierżawy ziemi pod wiatrak lub linię przesyłową. Informacje z wywiadów wskazują, że bezpośrednie korzyści finansowe uzyskuje tylko ok. 30 gospodarstw domowych w gminie (W8). W polskim prawie nie przewidziano rozwiązań, które rekompensowałyby obecność wiatraków wszystkim osobom mieszkającym w ich pobliżu. W tej sytuacji nie można mówić o sprawiedliwości energetycznej - tym bardziej że wraz z kolejnymi inwestycjami lokalnej społeczności obiecywano rekompensaty w postaci niższych rachunków za energię elektryczną. Tymczasem produkowany prąd przekazywany jest do sieci elektroenergetycznej i spółka energetyczna pobiera od mieszkańców miejscowości w pobliżu wiatraków takie same opłaty jak w innych gminach (W7, W8). Sytuacja ta nie podoba się zwłaszcza najstarszej grupie ankietowanych oraz osobom z wykształceniem podstawowym, które prawdopodobnie dysponują mniejszymi dochodami.

Ustawa o inwestycjach w zakresie elektrowni wiatrowych określa minimalną odległość od zabudowy rzędu dziesięciokrotności wysokości turbiny wraz ze śmigłem. Ogromna większość wiatraków w gminie Kisielice nie spełniłaby tego warunku. Mieszkańcy uznają granicę $1 \mathrm{~km}$ za optymalną odległość od zabudowy - taki sam procent respondentów dopuszczał turbiny bliżej oraz taki sam dalej. Analiza przestrzenna wykazała jednak, że $60 \%$ przedstawicieli gospodarstw domowych chciałoby bardziej 
odsunąć wiatraki od swego domostwa. Najmniejszą odległość, patrząc zarówno na średnią, jak i na medianę, podali respondenci z Łodygowa, gdzie farma wiatrowa istnieje już prawie 10 lat, a turbiny położone są regularnie. Dużo bardziej zachowawczy byli natomiast mieszkańcy Biskupiczek, gdzie wiatraki są położone najdalej od farmy.

Oprócz wiatraków zapytano w ankiecie także o minimalną odległość biogazowni od zabudowy. O ile biogazownia w Kisielicach jest powszechnie rozpoznawalna, o tyle mieszkańcy mają małą wiedzę na temat specyfiki inwestycji oraz jej potencjalnej uciążliwości dla środowiska. Wśród osób starszych dominuje niechęć do ewentualnego lokowania tego rodzaju instalacji w swej miejscowości. Jednocześnie znaczna część respondentów kojarzy biogazownię z nagrodami, które gmina otrzymała na szczeblu europejskim. Tym samym można powiedzieć, że przeważają pozytywne opinie na temat tego rodzaju inwestycji, choć średnia pożądanej odległości od zabudowań mieszkalnych jest wyższa niż w przypadku turbin wiatrowych.

\section{Wnioski}

Gmina Kisielice stanowi modelowy przykład wykorzystania potencjału endogennego oraz konsekwentnie wdrażanej polityki rozwoju lokalnego - co słusznie stawia ją na pozycji jednego z najciekawszych poligonów transformacji energetycznej w Polsce. Przykład Kisielic pokazuje, że OZE mogą przynosić istotne dochody dla samorządów, a także korzyści związane z poprawą stanu środowiska oraz możliwością kreowania lokalnych rynków zbytu. Kisielice wskazują też innym samorządom, że pomimo szczątkowych kompetencji ustawowych zdeterminowana gmina może z powodzeniem prowadzić politykę energetyczną i dzięki niej pozyskiwać środki na inwestycje własne lub realizowane z funduszy unijnych w ramach współfinansowania przez Unię Europejską.

Zdaniem badanych mieszkańców gminy wiatraki mają niewielki wpływ na krajobraz, turystykę, atrakcyjność zamieszkania i przyrodę, co w dużej mierze wynika z kombinacji przyzwyczajenia do codziennego widoku, niepełnej świadomości i relatywnie niskiej atrakcyjności krajobrazowej gminy. W poddanych badaniu miejscowościach poparcie dla rozwoju odnawialnych źródeł energii jest zbliżone do krajowego. Istotnym czynnikiem różnicującym stosunek lokalnej społeczności do energetyki wiatrowej jest regularność odstępu turbin względem siebie. Osoby mieszkające blisko skupisk regularnie usytuowanych wiatraków ogólnie lepiej odnoszą się do energetyki wiatrowej niż mieszkańcy obszaru, gdzie są one usytuowanie bardziej chaotycznie.

Na podstawie badań ankietowych można stwierdzić, że mieszkańcy zgadzają się na rozwój OZE, a także tolerują obecność wiatraków w gminie, jakkolwiek oczekiwaliby rozwiązania, które rekompensowałby wszystkim mieszkańcom bliskość instalacji w bardziej bezpośredni sposób niż remonty dróg oraz wiejskie imprezy. Obecnie 
wiatraki nie tyle przeszkadzają, ile wzbudzają poczucie niesprawiedliwości, ponieważ zysk z inwestycji czerpie jedynie niewielka część gospodarstw domowych. Chęć czerpania zysków dobrze obrazuje znaczny udział respondentów, którzy zgodziliby się posadowić wiatraki na swojej ziemi pomimo powszechnej opinii, że obecnie znajdują się zbyt blisko zabudowy. W przypadku elektrociepłowni, zgodnie z informacjami pochodzącymi z wywiadów, miejskie ciepło nie jest tak tanie, jak oczekiwaliby tego mieszkańcy, jednakże temat ten wymagałby przeprowadzenia pogłębionych badań w samym mieście.

Analizując cały okres prowadzenia polityki energetycznej Kisielic, można stwierdzić, że lokalna polityka energetyczna wpisała się w większość warunków społecznej akceptacji. Była lokalnie zakorzeniona (ze względu na wcześniejsze tradycje historyczne), tworzyła ciągłość z istniejącymi strukturami społecznymi/produkcyjnymi (farma wiatrowa w miejscu dawnego PGR), stosowane zaś procedury komunikacyjne i partycypacyjne należy uznać za odpowiednie. Kwestie korzyści lokalnych są już bardziej dyskusyjne - o ile gmina rzeczywiście istotnie się wzbogaciła dzięki wpływom podatkowym, o tyle zdaniem autora wszyscy mieszkańcy miejscowości powinni bardziej bezpośrednio odczuć profity inwestycji powszechnie uznawanych za uciążliwe np. w postaci niższych cen za energię elektryczną lub comiesięcznych opłat płaconych na rzecz spółdzielni energetycznej. Wówczas społeczna akceptacja dla transformacji energetycznej na poziomie lokalnym byłaby jeszcze wyższa.

Realizacja tego postulatu mogłaby znacząco ocieplić nadszarpnięty wizerunek energetyki odnawialnej wśród niektórych lokalnych społeczności. Do podjęcia tego rodzaju kroków potrzebna byłaby wola polityczna dalszego rozwoju samorządów opartego na odnawialnych źródłach energii na poziomie centralnym.

\section{Literatura}

Alanne K., Saari A., 2006, Distributed energy generation and sustainable development, Renewable and Sustainable Energy Reviews, 10 (6), 539-558.

Bednarek-Szczepańska M., 2016, Energetyka wiatrowa jako præedmiot konfliktów lokalizacyjnych w Polsce, Polityka Energetyczna - Energy Policy Journal, 19 (1), 53-72.

Calvert K., 2016, From "energy geography" to "energy geographies", Progress in Human Geography, 40 (1), 105-125.

Gadomska W., Antolak M., 2014, Landscape-related aspects of the siting of wind farms in Poland: A case study of the Great Masurian Lake District, European Spatial Research and Policy, 2 (21), 171-192.

Kłosowski W., Warda J., 2001, Wyspy Szans. Jak budowaćstrategie rozwoju lokalnego?, Biblioteka Rozwoju Regionalnego, Warda \& Kłosowski Consulting, Bielsko-Biała.

Kohoroda I., 2014, Kisielice - dobry przyktad dla polskich gmin, Globenergia, 6, 52-53. 
Komornicki T., 2016, Geografia spoteczno-ekonomiczna a terytorializacja polityki rowwoju, [w:] A. Suliborski (red.), Stan, perspektywy i strategia rozwoju geografii spoteczno-ekonomicznej w najblizszych latach (do 2030 r.). Dyskusja międzypokoleniowa, Wydawnictwo Uniwersytetu Łódzkiego, Łódź, 87-103.

Krzemiński J., 2014, Przykłady dobrych praktyk w sakresie budowy i wykorzystania biogazu. Warminsko-Mazurskie: gmina Kisielice, http://www.gmina.bio-gazownie.edu.pl/warminsko-mazurskie-gmina-kisielice (27.12.2016).

Lorenc H., 1996, Struktura $i$ sasoby energetyczne wiatru w Polsce, IMGW, Warszawa.

Łucki Z., Misiak W., 2010, Energetyka a spoteczenstwo. Aspekty socjologiczne, PWN, Warszawa.

Manwell J., McGowan J., Rogers A., 2009, Wind energy explained: Theory, design and application, Wiley, New York.

Marcinkiewicz J., Poskrobko T., 2015, Wptyw elektrowni wiatrowych na percepcje krajobrazu w Swietle badań empirycznych, Ekonomia i Środowisko, 53 (2), 76-91.

McCunney R., Mundt K., Colby D., Dobie R., Kaliski K., Blais M., 2014, Wind Turbines and Health: A Critical Review of the Scientific Literature, Journal of Occupational \& Environmental Medicine, 56 (11), 108-130.

Miller C., Iles A., Jones C., 2013, Social dimensions of energy transitions, Energy Research \& Social Science, 22 (2), 135-148.

Mroczek B., Banaś J., Machowska-Szewczyk M., Kurpas D., 2015, Evaluation of quality of life of those living near a wind farm, International Journal of Environmental Research and Public Health, 12 (6), 6066-6083.

Mroczek B., Kurpas D., 2014, Social attitudes towards wind farms and other renewable energy sources in Poland, Medycyna Środowiskowa - Environmental Medicine, 17 (4), 19-28.

NIK, 2014, Lokaliwacja i budowa lqdowych farm wiatrowych, NIK, Warszawa.

Niecikowski K., Kistowski M., 2008, Uwarunkowania i perspektywy rowwoju energetyki wiatrowej

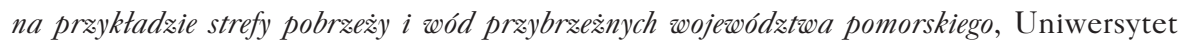
Gdański, Gdańsk.

Pasławski R., 2013, Kulisy konsultacji spotec*nych - biogazownie rolnicæe, Czysta Energia, 10, 24-26.

Pasqualetti M., 2011, Geography of energy and the wealth of the world, Annals of the Association of American Geographers, 101 (4), 971-980.

Pawlas K., Pawlas N., Boroń M., 2012, Życie w pobliæu turbin wiatrowych i ich wptyw na zdrowie - præeglad piśmiennictwa, Medycyna Środowiskowa - Environmental Medicine, 15 (4), 150-158.

Plan Gospodarki Niskoemisyjnej Gminy Kisielice do roku 2020, 2015, Powiślańska Regionalna Agencja Zarządzania Energią, Kwidzyn.

Popkiewicz M., 2016, Rewolucja energetyczna. Ale po co?, Sonia Draga, Warszawa.

Regulski A., Czauderna K., Frankowski J., Kalinowski H., 2016, Wptyw funduszy europejskich perspektywy finansowej 2007-2013 na rozwój spoteczno-gospodarczy Polski Wschodniej, Ministerstwo Rozwoju, Warszawa. 
Ruijven B. van, Urban F., Benders R., Moll H., Sluijs J. van der, Vries B. de, Vuuren D. van, 2008, Modeling energy and development: An evaluation of models and concepts, World Development, 36 (12), 2801-2821.

Simcock N., Mullen C., 2016, Energy demand for everyday mobility and domestic life: Exploring the justice implications, Energy Research \& Social Science, 18, 1-6.

Smil V., 2010, Energy transitions. History, requirements, prospects, Praeger, Westport.

Solomon B., Pasqualetti M., Luchsinger D., 2004, Energy Geography, [w:] G. Gaile, C. Willmott (red.), Geography in America at the Dawn of the 21st Century, Oxford University Press, Oxford, 302-313.

Sovacool B., Dworkin M., 2015, Energy justice: Conceptual insights and practical applications, Applied Energy, 142, 435-444.

Strategia na rzecz Odpowiedzialnego Rozwoju - projekt z dnia 27.09.2016 r., 2016, Ministerstwo Rozwoju, Warszawa.

Strategia Zrównoważonego Rowwoju Miasta i Gminy Kisielice na lata 2007-2020, 2007, Urząd Miasta i Gminy Kisielice, Kisielice.

TNS Polska, 2013, Energetyka wiatrowa, Raport TNS Polska dla Polskiego Stowarzyszenia Energetyki Wiatrowej, Warszawa.

Ustawa z dnia 20 maja 2016 r. o inwestycjach w sakresie elektrowni wiatrowych (Dz.U. 2016 poz. 961).

Wiklent G., Kistowski M., 2013, Wpływ przedsięwzięć elektroenergetycznych na wybrane elementy środowiska przyrodniczego i krajobraz gminy Pelplin, Problemy Ekologii Krajobrazu, 35, 19-44.

Wiśniewski G., Michałowska-Knap K., Arcipowska A., Dziarski P., 2012, Energetyka odnawialna jako dæwignia spoteczno-gospodarczego rozwoju województw do 2020 roku. Dlaczego warto i jak powinno się planować rowwój energetyki wiatrowej w regionach, Instytut Energii Odnawialnej, Warszawa.

Wiśniewski G., Michałowska-Knap K., Koć S., 2012, Energetyka wiatrowa - stan aktualny i perspektywy rozwoju w Polsce, Instytut Energii Odnawialnej, Warszawa.

WHO, 2006, Fuel for life. Household energy and health, WHO, Genewa.

Zatożenia do planu saopatræenia w ciepto, energie elektrycznq i paliwa gazowe dla obsæaru Gminy Kisielice na lata 2011-2026, 2012, Urząd Miasta i Gminy Kisielice, Kisielice.

\section{Wywiady wykorzystane w pracy}

Koprowiak T., W1, 2011, Konsekwentny plan Kisielic, http://www.chronmyklimat.pl/ (27.12.2016). Koprowiak T., W2, 2013, Nowe wiatraki stanq pod Jędrychowem $i$ Truplem, http://kurier-ilawski. $\mathrm{pl} /(27.12 .2016)$.

Koprowiak T., W3, 2014a, Gmina samowystarczalna energetycznie, http://modanazdrowie.pl (27.12.2016).

Koprowiak T., W4, 2014b, To sięoptaca. Wywiad burmistræem Kisielic, gdzie powstata biogazownia, http://samorzad.pap.pl (27.12.2016). 
Ryszczuk R., W5, 2015, Burmistr: Kisielic Rafat Rysz:uk: ,To OZE postawito na pana Koprowiaka”, http://infoilawa.pl (27.12.2016).

Koprowiak T., W6, 2015, Najbardziej sielona gmina w Polsce, http://zielonewiadomosci.pl (27.12.2016).

Ryszczuk R., Koprowiak T., W7, 2015, Kisielice pokazujq, jak energia odnawialna może pomóc w rozwoju, http://funduszeue.wp.pl (27.12.2016).

Ryszczuk R., W8, 2016, Kisielice juz nie cieszq się : OZE, http://rynekinfrastruktury.pl (27.12.2016).

Koprowiak T., W9, 2016, Kisielice nie «apomniały o swoim dawnym burmistræu Tomasะu Koprowiaku, http://kisielice.wm.pl (27.12.2016).

Jan Frankowski

Uniwersytet Gdanski

Instytut Geografii

ul. Bażyńskiego 4, 80-309 Gdańsk

jan.frankowski@univ.gda.pl 